\title{
6
}

\section{WEAK INSTITUTIONS, POSITIVE RESULTS}

\section{The European Union's response to Covid-19}

\author{
Beniamino Caravita, Simone Barbareschi, \\ Francesco Severa, Sergio Spatola and Adriano Dirri ${ }^{7}$
}

\subsection{Introduction}

The European Union (EU) experienced two waves of infection during the Covid-19 pandemic in 2020. The first wave, extending from March to May, came to notice when infections began to be detected in northern Italy on 21 February, after which the coronavirus spread across all 27 EU member states, with Italy and Spain initially the hardest hit countries. At the end of summer in Europe, this was followed by a second wave of the pandemic, in which contagion again affected the entirety of the EU but was characterised by faster rates of infection and had a heavy impact even on states, such as Germany, which fared relatively well in the first wave.

As at 31 October 2020, the EU had recorded a total of 10,020,313 cases and 273,734 deaths; economically, the effects of the first wave were keenly felt by the most fragile states, such as Italy and Spain, but during the second wave, it became clear that the pandemic was posing a serious economic threat to both the EU as a whole and each and every member state. The outbreak of Covid-19 put a major squeeze on the EU's institutional and economic framework, and the crisis it brought about shook the foundations of European integration.

This was all the more so because the pandemic found the EU already divided from within, on the one hand facing contestation by numerous member states (notably Poland, the Czech Republic, Slovenia, and Hungary) and, on the other, deeply concerned by Britain's exit, which came to pass on 31 January 2020, only a few weeks before the start of the pandemic. As a result, many reforms to the European Treaties were on the table, especially in regard to the empowerment of the European Parliament. In this context, the economic crisis underlined the division between the richer (the Netherlands, Belgium, and Germany) and poorer (Italy, Spain, and Greece) EU countries. 
This chapter aims to highlight the impact of Covid-19 on the federalising process of the EU. The main issues at stake are the dialectical relationship between the intergovernmental and supranational perspectives. The chapter describes the EU's response to the pandemic by analysing the EU's competence in disaster management and public health as well as the financial tools that exist for addressing economic crisis. Moreover, it assesses the role of the principle of solidarity and cooperation during the 2020 pandemic, with the focus on the European Commission and the financial measures that were adopted.

\subsection{The EU institutional and legislative framework}

\subsubsection{The EU system}

In this brief overview of the European institutional system, what is important to highlight is the constitutional nature of the EU: that is, it is not simply an international organisation, as it can enact legislation that is immediately applicable in its member states (Schütze 2020). The EU, in view of the economic scope of its federalising process, may be compared to a federal state. It is strikingly different, however, in its lack of two other typically federal areas: defence and foreign policy. Moreover, its notorious lack of strong democratic legitimacy prevents it from being traced back to the traditional liberal-democratic systems of government. Indeed, a true supranational dynamic fails to form in Europe, as EU institutions are forced to confront elected governments in member states.

As Fabbrini (2008) has argued, the EU may be defined as a 'compound democracy', a term referring to an institutional model characterised by a multiplicity of separations of power. The idea behind such a model is that neither member states nor individual institutions can gain a monopoly of decision-making. This function is thus entrusted to a subtle equilibrium and balancing between the different influences of the various institutional and political actors. Therefore, the functioning of the EU system is based on a partnership between the various institutions and on a mixture of functions, bound by the principle of loyal collaboration (Treaty on European Union, article 13, para. 2). The legislative and budgetary functions, for instance, are entrusted to the concurrent participation of Parliament and the Council (Fabbrini 2008).

A key role is played by the European Council, composed of heads of state or government of the member states, which stems from its political function. Although the Council does not exercise legislative power, it is the engine of the $\mathrm{EU}$ in that, for instance, it is empowered to define its general political direction, examine any subject of common interest, and, above all, decide on the revision of the treaties.

The European Parliament is the representative unit of the citizens of the Union and is elected, in its current composition of 751 members, every five years on a proportional basis, in consultation with all member states. In turn, the Council of the EU (the Council) is composed of government ministers from each EU 
country according to the policy area to be discussed. In regard to the approval of community acts, Parliament and the Council play an equal role in the ordinary legislative procedure; in regard to budgetary procedure, the two institutions have a co-decision role, both in the formulation and in the decision phase.

Next, the role of the European Commission is crucial because it retains the power of legislative initiative in the EU. According to article 17 of the Treaty on European Union, the Commission acts as the Union's 'government'. Its president is nominated by the European Council and elected by the European Parliament. Subsequently, the Council, in conjunction with the President-elect, adopts the list of commissioners. In addition to the role of proposal, which can be requested by Parliament and the Council, the Commission has other powers: (1) control over compliance with the obligations deriving from the treaties by the member states (infringement procedure); (2) administrative execution; and (3) inspection and supervision with respect to the division of responsibilities between the EU and the member states.

As for the European Court of Justice, it is a real judicial body. On the one hand, it exercises control over the lawfulness of the acts and conduct of EU institutions; on the other, it seeks to ensure correct and unambiguous interpretation of EU law.

The institutions above are supported by two financial institutions: the European Central Bank (ECB) and European System of Central Banks (ESCB). The first, based in Frankfurt am Main, has the task of directing EU monetary policy and authorising the issuance of the euro. The second - directed by the central banks of each member state - has the task of controlling price stability and contributing to the EU's general economic policies (Raffiotta 2020).

The complexity of the European institutional model makes it difficult for the EU to respond promptly and effectively in cases of extraordinary need and urgency. It is known that the supranational dynamic, flanked by and often opposed to the intergovernmental one, is not equipped with its own tools for immediate intervention. In fact, urgent measures must be agreed upon in the Council, even in the face of situations of grave risk and danger that involve the entire continent.

\subsubsection{European health law and disaster management}

The framework of EU health law derives from article 168 of the Treaty on the Functioning of the European Union (TFEU). The implications of the framework are numerous (Hervey and Bishop 2017), but what is significant here is that it lays down the competences of the member states and that of the EU, which are exclusive, shared, and supporting competences (Azoulai 2014).

Article 168 states that health protection shall be ensured in all EU policies and activities, which makes health a transversal policy. Nevertheless, the primary role is played by the member states, with national governments retaining this responsibility in managing the pandemic. In fact, paragraph 1 of article 168 
affirms that 'Union action, which shall complement national policies, shall be directed towards improving public health' and that, among other things, '[s]uch action shall cover the fight against the major health scourges'. The EU encourages cooperation among member states by supporting their actions and seeking to strengthen and coordinate dialogue between them (article 168, para. 2). It has rightly been observed that the EU 'mainly acts as a hub for rapid information exchange and coordination of national crisis' (Pacces and Weimer 2020: 286).

The complementary nature of the power of the EU in health law and policy is also understood on the basis of article 2, paragraph 5 of the TFEU. In certain matters, including the protection and improvement of human health, the Union may carry out actions to support, coordinate, or supplement the actions of member states without superseding their competences as listed in article 6 of the TFEU. This balance of power between the EU and member states is exemplified by article 168, even though paragraph 4 of that article lays down two derogations to the general principle.

In fact, on one hand, the TFEU allows the EU to overcome the limited power of the EU in health policies, by stating that the EU, in order to achieve the objectives in article 168, may adopt, through ordinary legislative procedure,

a. measures setting high standards of quality and safety of organs and substances of human origin;

b. measures in the veterinary and phytosanitary fields which have as their direct objective the protection of public health; and

c. measures setting high standards of quality and safety for medicinal products and devices for medical use.

In the second derogation, the EU is empowered to 'adopt incentive measures designed to protect and improve human health and in particular to combat the major cross-border health scourges, measures concerning monitoring, early warning of and combating serious cross-border threats to health ...' (TFEU, article 168, para. 5).

On the other hand, the same paragraph excludes any harmonisation of the laws and regulations of member states. In this regard, paragraph 7 further specifies that 'Union action shall respect the responsibilities of the Member States for the definition of their health policy and for the organisation and delivery of health services and medical care', including 'the management of health services and medical care and the allocation of the resources assigned to them'.

This short appraisal highlights the complementary nature of EU health law and policy and the constraints upon it, albeit that the power of the EU has been considered broader than what can be ascertained from the core provisions. It has been argued that the holistic approach may lead to a wider range of legal options for the EU through the interplay of the provisions of the treaties, such as the precautionary and proportionality principles and the right to health care in article 35 of the European Charter of Fundamental Rights (Purnhagen et al. 2020). 
Similarly, the scope of article 168, paragraph 7 may be broader, given the emphasis placed on cooperation between the Union and its member states and between the member states themselves. As the experience of Covid-19 has shown, it is better to speak in terms of interconnections and symbiotic relationships between the levels of the Union and the states (Guy 2020: 3).

During the 2020 pandemic, lack of cooperation and coordination between the Union and the member states emerged specifically in relation to one of the pillars of the EU: the free movement of persons. The Schengen Borders Code (Regulation EU 2016/399) allows the suspension of controls on external borders in case of a threat to public policy (article 2, para. 21; article 6, subpara. 6) and internal borders (article 25) in case of serious threat to public policy or internal security. The EU response in this regard was compromised in that internal borders were gradually closed by the member states.

The EU has no power to declare a state of emergency since this is not included among its exclusive competences. The coordinator of the European Emergency Response is the European Commissioner for Crisis Management, under which administration falls the EU Civil Protection Mechanism. In the context of Covid-19 and the economic crisis to which it led, the EU had to discuss and adopt new and broader economic mechanisms than it had in the past.

\subsection{Preparedness for disaster: The institutional framework}

As noted, the EU does not have competence in health matters and disaster management: it thus plays the role of coordinator for the member states. This is the operative logic of the EU Civil Protection Mechanism, the legal basis of which lies in article 196 of the TFEU. The Mechanism was established in 2001 and reformed in 2013 with the adoption of Decision No. 1313/2013/EU (Widmalm et al. 2019: 11-12). Its purpose is

to strengthen the cooperation between the Union and the member states and to facilitate coordination in the field of civil protection in order to improve the effectiveness of systems for preventing, preparing for and responding to natural and man-made disasters. (article 1, para. 1)

The Mechanism is clearly designed for a 'classical' disaster along the lines of a natural disaster (Bouckaert et al. 2020: 769), but it was strengthened in March 2019 by RescEU, an ad hoc tool that uses EU internal funds, pre-committed national funds and Union co-financing to enhance the EU's capabilities to face a major emergency (Purnhagen et al. 2020: 299; Widmalm et al. 2019: 177). RescEU was created particularly for providing assistance when member states are affected by unexpected disasters and collective capacity is insufficient.

The EU's framework for crisis preparedness and responding to cross-border health threats was adapted after previous viral outbreaks such as severe acute respiratory syndrome (SARS) and bird flu (H1N1). The reform of 2013 was 
aimed at providing rules on epidemiological surveillance, early warnings, and combating serious cross-border threats to health. At its core, once again, are cooperation and complementation of national policies in regard to managing epidemiological threats.

The main operative tools are the Early Warning and Response System (EWRS) and Health Security Committee (HSC), composed of representatives of member states (generally health ministers) and tasked with exchanging information about disease outbreaks within and outside the EU. In addition, the European Centre for Disease Prevention and Control (ECDC) monitors outbreaks and provides guidance on risk management. The ECDC, together with the HSC, plays an important role in managing pandemics, as it did during the Zika and Ebola outbreaks; nevertheless, the agency is hampered by, among other things, a lack of financial resources and cooperation among member states (Renda and Castro 2020: 276-7).

Last but not least, the operative tool for providing medical equipment such as masks, gloves, and ventilators is the Joint Procurement Agreement (JPA), introduced in 2014. The JPA has the task of boosting the EU's capacity to buy medication and vaccines before and during health crises. It is thus a further instrument aimed at fostering greater cooperation in matters of public health (AzzopardiMuscat et al. 2017).

Regarding economic aid, what tools did the EU have at its disposal when the pandemic began? We refer to the measures adopted in the aftermath of the 20082012 financial crisis (Tuori and Tuori 2014; Morrone 2015) and their implementation until December 2019. There are two areas of intervention: the measures taken to overcome the financial crisis and those adopted to overcome the sovereign debt crisis. Both can be summarised by grouping, on the one side, the institutional and regulatory responses and, on the other, those at the policy level.

At the institutional level, the EU established the European System of Financial Supervision (ESFS) and the Banking Union (BU) for member states which desire to participate. At the policy level, it enhanced micro-prudential and macroprudential rules for banks; established a banking crisis management system; and strengthened the regulatory framework for the non-banking system, which includes insurance and occupational pensions, non-bank financial intermediaries, and market infrastructure sectors (Hinarejos 2015: 15).

As for measures taken to face the sovereign debt crisis, in terms of policies the EU established the European Financial Stability Mechanism (EFSM), the European Financial Stability Facility (EFSF), the European Stability Mechanism (ESM), and the European Fiscal Board (EFB). Economic governance undoubtedly changed due to the global financial crisis of 2007/2008 (Fabbrini 2015). Thus, the EU was more than ready to face a further economic crisis, both in terms of coordination between member states and in terms of financial measures, thanks in particular to the policies of the ECB, with its injection of liquidity buffers and bail-in options, during the mandate of Mario Draghi, president of the ECB between 2011 and 2019 (Waibel 2020; Bofinger 2020). 
These were the main response mechanisms available to the EU for facing pandemic threats and economic crises. It has to be acknowledged that, in matters of health policy, the EU's network of agencies was not designed for engaging directly with a full-scale pandemic like Covid-19; moreover, the economic crisis of 2020 is regarded as the worst Europe has faced since the end of the Second World War.

\subsection{Rolling out measures to contain the pandemic}

\subsubsection{Taking the initiative}

Although it has been said that the EU lives off crises (Cassese 2016; Matthijs 2020), the Covid-19 pandemic was an unprecedented situation for the EU. Therefore, it should not be a surprise that, at the outset, its response was inadequate, coordination was missing, and EU institutions hesitated to act. Indeed, the measures taken were not decisive in preventing the outbreak.

In January 2020, an alert was issued on the EWRS by the Directorate General for Health and Safety, after which the HSC met on 17 January. Subsequently, on 28 January the Council of the European Union decided to activate the Integrated Political Crisis Response (IPCR) mechanism. The mechanism is, in particular, the EU framework for the coordination of cross-sectoral crises. The role of this body was later enforced when the Council, on 2 March, escalated the IPCR mechanism to full activation mode for coordinating EU response measures at presidency-led roundtables with the participation of the Commission, the European External Action Service, the office of the President of the European Council, affected member states, and relevant EU agencies and experts.

This was the first stage of coordination of the EU but, when the outbreak in Italy took place and the first red zones were declared, the main issue at stake was the closure of internal borders. In late February, within the EU, internal border control was under the spotlight. On 24 February 2020, with the outbreak in Italy already underway, the European Commissioner for crisis management was confident in the capacity of Italy and the EU to respond to the outbreak. Likewise, the Commissioner for Health and Food Safety stressed that the key points would have been cooperation, coordination, and keeping the borders open, with the closure considered as a disproportionate measure.

Of the same view was the Council of the European Union, which on 20 February 2020 highlighted the need for coordination between member states in the field of monitoring and surveillance, diagnosis and treatment and communications, research, and development. Furthermore, the Council, on the basis of Decision No. 1082/2013/UE, called upon the Commission to promote crosssectoral information-sharing and cooperation on surveillance, risk management, and assessment, with the support of the HSC and UCPM, and to activate existing funding mechanisms to support member states in facing the outbreak; and to examine all available possibilities, such as joint procurement, to facilitate access to personal protective equipment (PPE) needed by member states. 
Hence, the EU's initial action was to provide expertise and foster coordination. To this end, on 17 March 2020, the Commission appointed a new EU advisory panel on Covid-19. It was tasked to advise the Commission president, Ursula von der Leyen, on the measures to be taken, and to help the Commission in the development of guidance for member states in order to ensure science-based and coordinated national risk management. In addition, the HSC added a further forum for coordinating measures against the Covid-19 outbreak, with this body composed of national health ministers and chaired by the Commission. This structure thus entails the Commission and the HSC supported by the ECDC, scientific and technical bodies, and the newly established advisory panel (Pacces and Weimer 2020: 291).

A more concrete instrument for providing medical supplies was the JPA, which emerged, with RescEU, as the main vehicle at the EU level for purchasing medical equipment such as PPE, ventilators, and devices for testing. At the end of February 2020, the Commission launched the first of four joint procurement competitions; these were concluded in March, even though the first went defunct (McEvoy and Ferri 2020: 8; Sdanganelli 2020: 2339). In the interim, the Commission created a strategic RescEU stockpile of medical equipment, the budget for which amounted to EUR 50 million, with 90 per cent of it financed by the Commission and the balance by member states; the stockpile was managed by the Emergency Response Coordination Centre. The Commission's other initial measure was allocating EUR 232 million for boosting preparedness, prevention, and containment.

The more critical issue remained border control. The first member state to unilaterally close its border was Austria, which did so on 11 March 2020 when the World Health Organization declared the pandemic. Many others decided to follow suit. On $16 \mathrm{March}$, the Commission eventually introduced border controls in terms of article 25 of the Borders Code and established guidelines for an integrated approach. The closure of internal borders was a milestone in the management of the crisis, one that marked the moment when EU institutions became aware of the unique health and economic crisis they were facing (Brehon 2020: 5; Maurice et al. 2020: 1-2).

\subsubsection{EU action}

The border closures in the EU may be considered the red line for awareness of the magnitude of the crisis; as such, the need for significant and coordinated action became the main concern. The first step was the meeting of the Council on 10 March 2020, at which the EU's priorities were set out: limiting the spread of the virus, ensuring the provision of medical equipment, promoting research, and tackling the pandemic's socio-economic consequences. The second conference, held on 17 March, focused on the provision of medical equipment, particularly masks and respirators, and helping EU citizens stranded in third-party countries. 
From this moment on, intergovernmental relations became the engine of the EU institutions. For instance, on 18 March 2020, EU transport ministers, together with the European Commission, joined forces to keep priority traffic moving in order to maintain economic continuity, protect the health and safety of transport workers, and ensure their free movement across borders (the situation was discussed further at a meeting of foreign affairs ministers on $23 \mathrm{March}$ and 6 April). On the same date, the Council went on to give the go-ahead to support member states from the EU budget through the approval of legislative proposals that would free up funds to support small- and medium-sized enterprises (SMEs) and strengthen investment in products and services necessary to bolster health services in response to the crisis.

On 19 March 2020, EU ministers relevant to the Commission's proposal on the Coronavirus Response Investment Initiative (CRII) presented their positions and plans for a possible reallocation of EU funds for new initiatives to address the social and employment consequences of Covid-19. Soon afterwards, finance ministers agreed to ease EU fiscal rules and apply maximum flexibility so as to allow member states to take all necessary measures to support health, the civil protection system, and the economy.

On 26 March 2020, after the extraordinary G20 leaders' video conference, European Council members held a third video conference on Covid-19. Upon the assessment of the EU's response to the pandemic, the member states invited the Eurogroup (the informal body for informal meetings of the ministers of the euro area member states) (Craig 2017) to present proposals within two weeks. Once a slot waiver ${ }^{2}$ was adopted to help airlines, the EU amended legislation on structural and investment funds to accommodate greater flexibility and release EUR 37 billion, which was allocated to the CRII and EU Solidarity Fund.

In April 2020, the contagion escalated, as did its socio-economic impact. On 8 April, the Council approved a further use of so-called cohesion resources, offering a second package of measures, the Coronavirus Response Investment Initiative Plus (CRII+), to free up other money from EU structural funds for crisis-related operations. The development ministers, for their part, gave the green light to a package with overall financial support amounting to more than EUR 20 billion drawn from existing external action resources. This aid was followed by two financial decisions. First, Eurogroup contemplated three immediate safety-nets for workers, businesses, and member states and prepared the ground for a recovery fund; secondly, the Council adopted two amendments to the EU 2020 budget that made an additional EUR 3.1 billion available in funds to purchase and distribute medical supplies, boost the production of testing kits, build field hospitals, and transfer patients for treatment in other member states.

In May 2020, concrete action was taken. On 8 May, for instance, Eurogroup agreed on standardised terms for Euro-area countries to access the ESM Pandemic Crisis Support. Member states were allowed access to 2 per cent of their gross domestic product (GDP) to finance direct and indirect health care as well as preventative measures related to Covid-19. On 19 May, the EU adopted a temporary 
scheme to help workers keep their jobs during the crisis. Under the scheme, the European Commission would raise funds on international capital markets on behalf of the EU, while the member states would be able to request up to EUR 100 billion in loans under favourable terms to help finance sudden and severe increases of national public expenditure in response to the crisis in specific areas. Support to the audio-visual, cultural, and creative sector; aid to help transport companies and authorities, a EUR 3 billion assistance package for neighbouring partners; and recovery measures for the EU tourism, aviation, and railway sectors all followed from those actions.

May 2020 closed with two important events. In the first, the Board of Directors of the European Investments Bank (EIB) reached an agreement on the new pan-European guarantee fund to support businesses. This was the second of the three safety-nets, worth EUR 540 billion, for jobs and workers, businesses, and member states, after the Support to mitigate Unemployment Risks in an Emergency (SURE) was adopted by the Council on 19 May. In the second event, the European Commission issued its proposal for a recovery fund and the EU's long-term budget, the multiannual financial framework (MFF) for 20212027. Consequently, the President of the European Council called for a meeting for this purpose in mid-July.

In addition, ministers dealt with the future of the EU in this recovery programme. Specifically, they addressed research and innovation, space, safe sport activities, digital priorities, internal border controls and free movement of persons, trade policy implications, and resilient labour markets. Last but not least, they considered how to shape Europe's digital future and reinforce the EU4Health programme and its objectives for 2021-2027, with the focus on strengthening the resilience of health systems and promoting innovation in the health sector.

After the adoption of a recommendation on the gradual lifting of the temporary restrictions on non-essential travel into the EU for residents of some thirdparty countries, the Council provided a temporary derogation from certain provisions of EU legislation in order to facilitate swift development of a vaccine against Covid-19.

The month of July 2020 was notable for a new proposal for the EU's longterm budget and recovery package ahead of the European Council session on 17-18 July, in which, after bitter negotiations between two very distant positions, EU leaders agreed on an extraordinary EUR 750 billion recovery package in the context of the European budget for 2021-2027. That aside, a more decisive effort was prompted on the implementation of testing and tracing, as well as on research on a vaccine for the coronavirus.

\subsubsection{Evaluating solidarity and cooperation}

The issues of solidarity and cooperation flow like subterranean rivers in the EU, underlying every political and legal debate on its future (Battaglia 2020; Borger 2020), be it in areas such as migration, tax policy, economic integration, or 
even Brexit. Solidarity, federal loyalty, and cooperation are at stake in federal systems and federalising processes generally. This is true as well of the EU, where these principles were developed during the European integration, mostly by the European Court of Justice (Lanceiro 2018: 74 ff).

The Lisbon Treaty introduced the principle of solidarity in article 3, paragraph 4, of the Treaty on European Union and of 'sincere cooperation' in article 4, paragraph 3, of the same, which imposes the duty that 'the Union and the Member States shall, in full mutual respect, assist each other'. These provisions are interlinked with each other as well as with article 13, which enshrines the duty of loyalty and fairness between EU Institutions.

It is worth recalling that solidarity is often under the spotlight due to its link to the issue of migration, in regard to which solidarity is specifically enforced by articles 78 , paragraph 3 , and 80 of the TFEU; nonetheless, migration has been a key point of contention since 2015. Similarly, the principle of solidarity has been challenged in the field of political economy, in the context of the inadequacy, or 'austerity' of approach which the EU, here largely influenced by its richer member states, has adopted.

Consequently, tests of solidarity and cooperation in the EU have become routine (Casolari 2014). The Covid-19 pandemic in 2020 was a further occasion for stress-testing the EU framework - in this instance, however, a framework under an extraordinary burden. On one hand, there were calls for solidarity among member states; on the other, differing economic interests, as well as the NorthSouth divide, overshadowed the development of inter-state trust and solidarity. Although solidarity is a yardstick for measuring the success or failure of the EU, it remains undefined in the Union's policies. Hence, what shall be considered here is the institutional performance, the praxis, both of the EU institutions (in particular the Commission) and of member states (Beaucillon 2020a: 688).

Initially, the Commission's response to the coronavirus was hesitant, but as the pandemic worsened, it acted on the basis of the principle of solidarity. That was evident in the case of the Civil Protection Mechanism and RescEU, described above, which aimed at coordinating member states and the collective response by the Commission. Denmark, Greece, Hungary, and Sweden joined Germany and Romania as host states of the RescEU medical equipment reserve which is available for distribution across Europe in medical emergencies (Beaucillon 2020b: 395-98). In a similar vein, European public procurement is an additional soft-law tool for fostering solidarity in concrete ways, in this instance by supporting member states in purchasing medical equipment. The Commission highlighted the relevance of the tool by publishing a guide on using the public procurement framework in the context of Covid-19. The purpose of the guide was to foreground the advantages of the European procurement process, such as its flexibility and transparency.

The Commission demonstrated involvement and solidarity with member states by underlining their common interests in combating the pandemic (Baratta 2020: 370-373). Another example is the Guidelines on EU Emergency 
Assistance in Cross-Border Cooperation in Healthcare related to the Covid-19 crisis, funded by the Solidarity Fund and developed to help national health-care systems under pressure. Among other things, the document provided for emergency transfers of patients in intensive care and the coordination of requested and offered intensive care places for patients (Capuano 2020: 28). The Commission also took action by proposing the provision of emergency aid on the basis of article 122 of the TFEU in the matter of economic policy (financial assistance in case of exceptional occurrences) and by adjusting the general budget of the Union (Beaucillon 2020b: 398).

The Commission initiated these measures, but ultimately decisions in regard to them lay with the European Council, the forum of EU leaders (the Master of the Treaties). These remarks lead us to the more problematic intergovernmental relations that obtained between member states. From the outset of the crisis, the response to the most affected country, Italy, was uncoordinated and bilateral. Only Austria provided assistance to it on the basis of the Civil Protection Mechanism (Beaucillon 2020b: 388-91). Shortly afterwards, the bone of contention between member states was the EU budget. The North-South division between member states was pronounced, especially because the so-called frugal four (the Netherlands, Austria, Denmark, and Sweden) advocated a meagre recovery fund based on loans instead of grants. Hence, evaluating the EU's solidarity in the face of the Covid-19 crisis entails examining the financial measures that were taken.

\subsubsection{Intergovernmental fiscal relations}

This section considers the main policies the EU adopted to support employment, businesses, and the economy in response to the Covid-19 pandemic. These may be summarised in terms of three themes: introducing flexibility into tax rules and the EU budget, the mobilisation of the EU budget, and the expansion of monetary policies.

\subsubsection{Flexibilisation of EU fiscal and budgetary rules}

The first assessment on the pandemic's socio-economic effects dates back to European Council conclusions on 'Competitiveness'. In the document of 27 February 2020, the Council, based on a note shared by the Commission, stated that the pandemic would have the effect of reducing the economic growth of the EU.

Upon the request of member states already affected at the time, the Commission, first of all, proposed to the Council that it deviate from the normal budgetary obligations of the Stability and Growth Pact (SGP) (Keppenne 2019) through the use of article 173, paragraph 3(b) of the TFEU (Domenicali 2020: 459-60). The latter, known as the 'general escape clause', allows for deviation from (1) the process of approaching the medium-term objective, (2) the stability and convergence programmes, and (3) correction in the event of an excessive deficit. 
The choice to use this clause, rather than the so-called unusual event clause, is to be traced back to the involvement of the entire euro area in the pandemic crisis. This does not indicate that the EU has used a rule designed for this type of event. As we will see regarding other financial measures, the EU has interpreted the rules, taking advantage of the experience of the last decade. Indeed, it is certain that the clause was not designed to encourage an economic recovery of the euro area, but for the sole purpose of system stability.

Furthermore, the Commission accompanied the deviations above with derogatory measures from the European regulatory framework. A derogation was envisaged from the rules on state aid not because of individual programmes proposed by each member state but for cumulative and simultaneous adoption by all member states. This method of application freed the member states as regards the choice of ways to support their economies. The only constraints, in fact, were the temporary nature of the measures, the connection to the assumptions set by the Commission, and to the verifiability of the measures taken (Domenicali 2020: 460).

It is precisely this last requirement that made it possible to affirm an expansion of the political orientation of each member state in this matter. The consequence is that the clause is transformed from an exceptional to a general instrument to safeguard the economic and financial stability of the euro area.

\subsubsection{Mobilisation of the EU budget}

The Commission, having realised that the crisis would be Europe-wide, complained that the EU budget was too small for addressing its socio-economic dimensions. It thus reallocated part of the European funds to deal with the crisis, creating a package of EUR 37 billion of structural funds (CRII) and implementing it via the CRII+. The three measures considered strategic were supporting health care, protecting short-term employment positions, and assisting SMEs.

The approval of the funding package made it necessary to amend the regulations governing the Common Provisions Regulation, European Regional Development Fund, and European Maritime and Fisheries Fund. The amending regulation grants flexibility to the states both in relation to the transfer of the sums allocated between the three cohesion funds (European Regional Development Fund, European Social Fund, and Cohesion Fund) and between different categories of regions, both in relation to the methods of expenditure and the criterion of thematic cohesion.

The same system of flexibility and modification of the destination of allocations was used for the EU Solidarity Fund. Finally, about EUR 3 billion in funds were used to directly support the health systems of the member states, through the EU emergency support instrument for the health-care sector. With regard to the mobilisation of the EU budget, this was the instrument for the extraordinary measure of the Next Generation EU recovery fund (discussed below). 


\subsubsection{Expansion of monetary policies}

The ECB confirmed, with the Pandemic Emergency Purchase Programme (PEPP), the use of unusual monetary policies previously developed in the aftermath of the global financial crisis of 2008. The PEPP, which had a total budget of EU 750 billion, was limited in duration to 2020 and it was flexible in the forms of debt it made available through the central banks that include the ESCB. In addition, the ECB provided for the extension of eligible assets for the purposes of the Corporate Sector Purchase Programme and interventions on interest rates and financing transactions as well as support measures for the disbursement of bank loans with the simultaneous relaxation of disbursement criteria.

\subsubsection{Next Generation EU}

The adoption of the Next Generation EU recovery fund was a major step forward because its purpose was to increase the European budget by 0.6 per cent. The increase was to obtain liquidity in the financial markets through debt operations. Furthermore, a reform of the Union's own resources was envisaged.

The debt of the Union must have a maximum threshold of EUR 750 billion. The sums obtained from the operation were to be diverted to the member states, in part through loans and partly through direct funding, for the achievement of the EU's strategic objectives. One of the key features is the role of the European Commission: the latter's role was strengthened in that the Commission sets the agenda and verifies the recovery plan of each member state.

The device for recovery and resilience, according to article 175, paragraph 3 , of the TFEU, is a structural fund aimed at reinforcing cohesion. It should enable member states to recover more quickly and increase their future resilience. As for the timing of disbursement to the member states and the terms of commitment of the sums, 70 per cent had to be committed by the beneficiary countries in 2021 and 2022 and the remaining 30 per cent by the end of 2023 . However, all funds had to be spent by 31 December 2026.

Finally, as regards distribution criteria, for the two-year period 2021-2022 funds were to be based on population, per capita GDP, and average unemployment rate in the last five years (2015-2019) compared to the EU average. For 2023, on the other hand, the loss of real GDP observed over 2020 and the cumulative loss of real GDP observed in the 2020-2021 period would replace the average unemployment rate in equal percentages. That being noted, own resources constitute the real innovative core of the 'extraordinary' instrument; in fact, resources from carbon tax, financial transactions, and business income were often extolled as the beginning of this path.

In conclusion, Europe managed to capitalise on the decade spent consolidating its regulatory framework after the 2008 financial crisis by harnessing these gains in order to offset the socio-economic impact of the pandemic more quickly. It is clear that the extraordinary increase of the EU budget represents 
an opportunity to revive the process of European integration, pursue the unification of the political economy, and build a fiscal union that transcends the differences among member states (Fasone 2020). In fact, several studies now consider the separation between economic and monetary policy to be irreconcilable (Howarth and Verdun 2020; Demertzis and Wolff 2019). The latter is no longer considered relevant to the economic development of the member states. An alltoo-recent and vivid example is provided by the repercussions that the monetary policies of the ECB have had on the economic policies of each member state.

\subsection{Findings and policy implications}

The Covid-19 pandemic was an important test for the EU and a turning-point in European history. It forced a rethinking of the EU's fiscal and budgetary rules, as well as its instruments for providing financial assistance to ailing states. After an initial phase of weak coordination in managing the emergency, especially within the health-care sector, European institutions decided to implement more effective measures when it came to economic governance.

It can be argued that during 2020 a new political reasoning began to prevail, one focused no longer on the intergovernmental dynamic but on a new centrality of European institutions and therefore on the more properly supranational dynamic. The European conundrum and its federalising process have been shaped by moments of integration and moments where the division between member states seemed to give way to disintegration (Vollaard 2018). Currently, the EU is fractured not only by economic differences between the North and the South but by diverse geopolitical interests (Atlantic, Continental, and Mediterranean). In juxtaposition to this, supranational institutions were created to mediate between member states, among them the Commission, the ECJ, and, more recently, the ECB.

This dialectical relationship may be measured by European policy, especially in times of crisis. In this perspective, then, the outcome of the European Council session of July 2020 may be considered a step forward more for the integration dynamic than for the intergovernmental dynamic. The latter has led, even perhaps in a despotic manner, European processes in the last decade; by the same token, enforcing the supranational dimension raises the issue of democratic legitimacy which has so weakened EU supranational institutions. Consequently, the risk is that the interests of the member states will prevail, along with their respective nationalisms. Indeed, even the European Parliament, the sole legislative body directly elected by European citizens, plays only a marginal role in determining EU policies. In this regard, before the pandemic took the limelight, a Conference on the Future of Europe was planned and the call was for, among other things, the empowerment of the European Parliament.

The European Council decisions of July 2020 did not propose a definitive solution to the European integration process, but they did open a new perspective. This led member states of the Union to accept the guarantees and negotiations 
of the European institutions in the management of economic tools for supporting the economy of the member states. Moreover, the pandemic showed that, despite the huge allocation of funds, the EU is not able to face emergencies as such. The issue on the table is, hence, to rethink the distribution of the EU competences in order to bolster the Union's response in the future to emergencies such as pandemics. To sum up, the lesson that can be learnt from Covid-19 is that there is a need for concrete solidarity, and in this regard, the actions of the Commission have revealed that it is crucial in the management of crisis situations.

\section{Notes}

1 This chapter is part of the research undertaken by 'Osservatorio sui processi di governo e sul federalismo' and also a product of the Project of Research of National Interest (PRIN 2017): 'Where is Europe going? Paths and perspectives of the European federalising process' (Principal Investigator: Prof. Beniamino Caravita).

2 To control congestion at airports, airlines are assigned fixed periods, or slots, during which their planes may land or take off. The rule is that if an airline fails to use a certain proportion of its slots, it loses them to its competitors. Slot waivers were intended to allow airlines to reduce flights to only necessary ones, without the risk of forfeiting their commercially valuable slots.

\section{References}

Azoulai, L. 2014. The Question of Competence in the European Union. Oxford: Oxford University Press.

Azzopardi-Muscat, N. et al. 2017. 'The European Union Joint Procurement Agreement for Cross-border Health Threats: What Is the Potential for This New Mechanism of Health System Collaboration?', Health Economics, Policy and Law, 12(1): 43-59.

Baratta, Roberto. 2020. 'EU Soft Law Instruments as a Tool to Tackle the COVID-19 Crisis: Looking at the "Guidance" on Public Procurement through the Prism of Solidarity', European Papers, 5(1): 365-73.

Battaglia, Francesco. 2020. 'Il principio di leale cooperazione nel Trattato di Lisbona. Una riflessione sulle vicende legate al recesso del Regno Unito dall'Unione europea', Federalismi. it, 19: 23-53.

Beaucillon, Charlotte. 2020a. 'European Solidarity in Times of Emergency: An Introduction to the Special Focus on COVID-19 and the EU', European Papers, 5(1): 687-9.

Beaucillon, Charlotte. 2020b. 'International and European Emergency Assistance to EU Member States in the COVID-19 Crisis: Why European Solidarity Is Not Dead and What We Need to Make It Both Happen and Last', European Papers, 5(1):387-401.

Bofinger, Peter. 2020. 'The ECB's Policy under the Presidency of Mario Draghi: A Curse or a Blessing for Europe?', European Journal of Economics and Economic Policies: Intervention, 17(2): 171-82.

Borger,Vestert. 2020. The Currency of Solidarity. Cambridge: Cambridge University Press.

Bouckaert, G. et al. 2020. 'European Coronationalism? A Hot Spot Governing a Pandemic Crisis', Public Administration Review, 80(5): 765-73.

Brehon, N-J. 2020. 'The European Union and the Coronavirus', Policy Paper No. 553, European Issues - Foundation Robert Schumann Foundation, pp. 1-10.

Capuano, Valeria. 2020. 'Covid-19 e libera circolazione dei servizi sanitari: un esempio di solidarietà europea?', AISDUE, Sezione 'Coronavirus e diritto dell'Unione', 3: 21-31. 
Casolari, Federico. 2014. 'EU Loyalty after Lisbon: An Expectation Gap to Be Filled?', in Lucia Serena Rossi and Federico Casolari (eds), The EU after Lisbon:Amending or Coping with the Existing Treaties? Basel: Springer.

Cassese, Sabino. 2016. 'L'Europa vive di crisi', Rivista trimestrale di diritto pubblico, 3: 779-90.

Craig, Paul. 2017. 'The Eurogroup, Power and Accountability', European Law Journal, 23: 234-49.

Demertzis, Maria, and Guntram B. Wolff. 2019. 'What Are the Prerequisites for a Euro Area Fiscal Capacity?', Journal of Economic Policy Reform, 23(3): 267-72.

Domenicali, Caterina. 2020. 'La Commissione europea e la flessibilità "temporale” nell'applicazione del Patto di Stabilità e Crescita', Federalismi.it, 19: 453-62.

Fabbrini, S. 2008. Compound Democracies: Why the United States and Europe Are Becoming Similar. Oxford: Oxford University Press.

Fabbrini, S. 2015. Which European Union? Europe after the Euro Crisis. Cambridge: Cambridge University Press.

Fasone, Cristina. 2020. 'Le conclusioni del Consiglio europeo straordinario del 21 luglio 2020: una svolta con diverse zone d'ombra', Diritti comparati, 21 July.

Guy, Mary. 2020. 'Towards a European Health Union: What Role for Member States?', European Journal of Risk Regulation, 11: 307-316.

Hervey, Young and Louise E. Bishop (eds). 2017. Research Handbook on EU Health Law and Policy. Cheltenham: Edward Elgar.

Hinarejos, A. 2015. The Euro Area Crisis in Constitutional Perspective. Oxford: Oxford University Press.

Howarth, David and Verdun, Amy. 2020. 'Economic and Monetary Union at Twenty: A Stocktaking of a Tumultuous Second Decade: Introduction', Journal of European Integration, 42(3): 287-93.

Keppenne, Jean-Paul. 2019. 'Fiscal Rules', in Federico Fabbrini and Marco Venturozzo (eds), Research Handbook on EU Economic Law. Cheltenham: Edward Elgar.

Lanceiro, Rui Tavares. 2018. 'The Implementation of EU Law by National Administrations: Executive Federalism and the Principle of Sincere Cooperation', Perspectives on Federalism, 10(1): 71-102.

Matthijs, Matthias. 2020. 'Lessons and Learnings from a Decade of EU Crises', Journal of European Public Policy, 27(8): 1127-1136.

Maurice, Eric, Thibault Besnier and Marianne Lazarovici. 2020. 'Restoring Free Movement in the Union', Policy Paper No. 562, European Issues - Foundation Robert Schumann Foundation, pp. 1-9.

McEvoy, E. and Delia Ferri. 2020. 'The Role of the Joint Procurement Agreement during the COVID-19 Pandemic: Assessing its Usefulness and Discussing Its Potential to Support a European Health Union', European Journal of Risk Regulation, 11: 1-13.

Morrone, A. (eds). 2015. La Costituzione finanziaria. La decisione di bilancio dello Stato costituzionale europeo. Torino: Giappichelli.

Pacces, Alessio M. and Maria Weimer. 2020. 'From Diversity to Coordination: A European Approach to COVID-19', European Journal of Risk Regulation, 11(2): 283-96.

Purnhagen, Kai P. et al. 2020. 'More Competences than You Knew? The Web of Health Competence for European Union Action in Response to the COVID-19 Outbreak', European Journal of Risk Regulation, 11(2): 297-306.

Raffiotta, Edoardo Carlo. 2020.'La Banca centrale europea a dieci anni dal Trattato di Lisbona tra emergenze e la ricerca di un'identità', Federalismi.it, 19: 345-60.

Renda, Andrea and Rosa Castro. 2020. 'Towards Stronger EU Governance of Health Threats after the COVID-19 Pandemic', European Journal of Risk Regulation, 11(2): 274-82. 
Schütze, R. 2020. An Introduction to European Law. Cambridge: Cambridge University Press. Sdanganelli, Gloria. 2020. 'Il modello europeo degli acquisti congiunti nella gestione degli eventi rischiosi per la salute pubblica', DPCE Online, 43(2): 2323-46.

Tuori, Kaarlo and Klaus Tuori. 2014. The Eurozone Crisis: A Constitutional Analysis. Cambridge: Cambridge University Press.

Vollaard, Hans. 2018. European Disintegration: A Search for Explanations. Cham: Palgrave Macmillan.

Waibel, Michael. 2020.'The EU's Most Influential Economic Policy-maker: Mario Draghi at the European Central Bank', European Journal of International Law, 31(1): 345-52.

Widmalm, Sten, Charles Parker and Thomas Persson (eds). 2019. Civil Protection Cooperation in the European Union How Trust and Administrative Culture Matter for Crisis Management. Cham: Palgrave Macmillan. 